\title{
Second-hand smoke in four English prisons: an air quality monitoring study
}

\author{
Leah R. Jayes ${ }^{1 *}$, Elena Ratschen ${ }^{1}$, Rachael L. Murray ${ }^{1}$, Suzy Dymond-White ${ }^{2}$ and John Britton ${ }^{1}$
}

\begin{abstract}
Background: To measure levels of indoor pollution in relation to smoking in four English prisons.

Methods: TSI SidePak AM510 Personal Aerosol Monitors were used to measure concentrations of particulate matter less than $2.5 \mu \mathrm{m}$ in diameter $\left(\mathrm{PM}_{2.5}\right)$ for periods of up to $9 \mathrm{~h}$ in selected smoking and non-smoking areas, and personal exposure monitoring of prison staff during a work shift, in four prisons.

Results: $\mathrm{PM}_{2.5}$ data were collected for average periods of $6.5 \mathrm{~h}$ from 48 locations on 25 wing landings where smoking was permitted in cells, on 5 non-smoking wings, 13 prisoner cells, and personal monitoring of 22 staff members. Arithmetic mean $\mathrm{PM}_{2.5}$ concentrations were significantly higher on smoking than non-smoking wing landings $\left(43.9 \mathrm{\mu g} / \mathrm{m}^{3}\right.$ and $5.9 \mathrm{\mu g} / \mathrm{m}^{3}$ respectively, $\left.p<0.001\right)$ and in smoking than non-smoking cells $\left(226.2 \mathrm{\mu g} / \mathrm{m}^{3}\right.$ and $17.0 \mathrm{\mu g} / \mathrm{m}^{3}$ respectively, $p<0.001$ ). Staff members wore monitors for an average of $4.18 \mathrm{~h}$, during which they were exposed to arithmetic mean $\mathrm{PM}_{2.5}$ concentration of $23.5 \mu \mathrm{g} / \mathrm{m}^{3}$.

Conclusions: The concentration of $\mathrm{PM}_{2.5}$ pollution in smoking areas of prisons are extremely high. Smoking in prisons therefore represents a significant health hazard to prisoners and staff members.
\end{abstract}

Keywords: Smoking, Passive smoking, Air pollution, Tobacco, Prison, Smoke-free

\section{Background}

Second-hand smoke (SHS) causes a range of harmful health effects including lung cancer, lower respiratory tract infections and cardiovascular disease; and exacerbates asthma [1-3]. Awareness of these effects has led governments in the UK and many other countries to introduce smoke-free legislation, and in England, legislation requiring all enclosed work and public places to become smoke-free came into force in July 2007 [4]. The significant reductions in exposure to SHS that this and similar legislation has achieved [5] has resulted in marked reductions in episodes of both cardiovascular and respiratory disease [6-8].

The English legislation did however provide some exemptions, one of which applied to prisons. Prison Service Instruction (PSI) 09/2007 enabled prison Governors in England to make landings and/or wings in prisons smoke-free, but allowed prisoners aged over 18 to smoke

\footnotetext{
* Correspondence: leah.jayes@nottingham.ac.uk

${ }^{1}$ UK Centre for Tobacco and Alcohol Studies and Division of Epidemiology and Public Health, University of Nottingham, Clinical Sciences Building, Nottingham City Hospital, Nottingham NG5 1PB, UK

Full list of author information is available at the end of the article
}

in single cells or in cells shared with other smokers [9]. Since around $80 \%$ of the approximately 85,000 prisoners currently detained in England and Wales smoke [10], levels of SHS in some indoor prison areas are likely to be very high, resulting in a significant potential hazard to prisoners, prison staff and visitors.

The concentration of airborne particulate matter $<2.5$ $\mu \mathrm{m}$ in diameter $\left(\mathrm{PM}_{2.5}\right)$ is a well-established marker of indoor SHS concentrations [11, 12], and previous studies have shown high $\mathrm{PM}_{2.5}$ concentrations in environments where smoking has taken place $[12,13]$. Although there is no safe level of SHS, standards for indoor air quality produced by the World Health Organisation (WHO) recommend that $\mathrm{PM}_{2.5}$ concentrations alone should not exceed $25 \mu \mathrm{g} / \mathrm{m}^{3}$ as a $24 \mathrm{~h}$ mean, or $10 \mu \mathrm{g} / \mathrm{m}^{3}$ as an annual mean [14]. Evidence to date on the concentration levels of particulate matter in prisons is limited however [15-17], with little information on ambient concentrations on wing landings or smoking cells, and to our knowledge, no data from prisons in England. This study was therefore carried out to measure $\mathrm{PM}_{2.5}$ concentrations, as a proxy measure for second-hand 
smoke, on prison landings and in smoking and nonsmoking cells; and by ambient monitoring as a measure of personal exposure of staff working in these settings.

\section{Methods \\ Prisons}

Data were collected from four English Prison Service establishments selected to provide variety in relation to security level, prisoner gender, structural design and size (Table 1). All four prisons had a no-smoking policy for staff members within the prison perimeter, though one had designated areas within the prison grounds for electronic cigarette use by staff members. Prisoners were only allowed to smoke in their prison cell with an exception of one prison which permitted smoking in the exercise yard over lunch periods for those who left the wing all day to work. All had smoke-free wings which included smoke-free cells (Table 1).

\section{Particulate pollution}

$\mathrm{PM}_{2.5}$ concentrations were measured using a batteryoperated SidePak Personal Aerosol Monitor AM510 (TSI Inc, MN, USA) fitted with a $\mathrm{PM}_{2.5}$ impactor and set to a calibration factor of 0.30 , as established in the literature to measure tobacco smoke $[18,19]$. In accordance with manufacturer's instructions, SidePak devices were cleaned, the impactor re-greased, zero-calibrated and the flow rate set at $1.7 \mathrm{l} / \mathrm{min}$ before each use. $\mathrm{PM}_{2.5}$ measurements were logged at one minute intervals, with each one minute data point being an average of $60 \mathrm{~s}$ of sample measurements.

\section{Data collection}

Data were collected over three to four consecutive days, typically from a Wednesday or Thursday to Saturday, so that sampling took place in both weekday and weekend regimes, and before and after the 'canteen' days when prisoners can purchase tobacco or other personal goods (typically Fridays). A researcher trained in the use of air quality monitoring and surveying, with the help of a prison service headquarters staff member, placed the SidePak monitors in static locations on wing landings and in prisoners' cells, or attached the monitor to wingbased prison staff to collect personal exposure data during parts of their work shifts.

Fixed locations on wing landings were chosen to cover the range of wing designs and function. Monitors were placed as discreetly as possible to avoid disturbing prisoners' normal behaviour, though wing officers knew where monitors were placed and for how long. The device was usually placed half way down the wing, above head height and away from open outside doors, windows, or cooking equipment. The monitor keypads were locked during sampling. We collected samples on each day for as long as the researcher was allowed access to the wing, and subject to limitations of battery life and in the case of personal monitoring, staff shift patterns. The gentle buzz emitted from the SidePak monitors could not be heard above the surrounding environmental noise during personal and wing sampling. Data on the layout of the wing, prisoner roll count and lock/unlock times were recorded. Prisoners who inquired were informed that we were measuring air quality.

Wing officers were asked to identify smoking and non-smoking prisoners who were suitable to have a SidePak monitor placed in their cell, and these prisoners

Table 1 Prison facility characteristics

\begin{tabular}{|c|c|c|c|c|c|c|}
\hline & $\begin{array}{l}\text { Category and } \\
\text { function }^{\text {a }}\end{array}$ & Structural design & Roll count & Wings & Smoke-free wings & Sampled \\
\hline HMP 1 & $\begin{array}{l}\text { Female } \\
\text { Closed } \\
\text { Local }\end{array}$ & $\begin{array}{l}\text { Built 1960s. Mix of original, T-shaped } \\
\text { and quick build wings }\end{array}$ & 262 & 7 & Mother \& Baby Unit & July 2014 \\
\hline HMP 2 & $\begin{array}{l}\text { Male } \\
\text { Category C } \\
\text { Training }\end{array}$ & $\begin{array}{l}\text { Built 1960s. Mix of triangular, T-shaped } \\
\text { and quick build wings }\end{array}$ & 494 & 8 & Care \& Separation Unit & August 2014 \\
\hline HMP 3 & $\begin{array}{l}\text { Male } \\
\text { Category B } \\
\text { Local }\end{array}$ & Built 1850s. Victorian radial design & 533 & 7 & Healthcare & August 2014 \\
\hline HMP 4 & $\begin{array}{l}\text { Male } \\
\text { Category B } \\
\text { Local }\end{array}$ & $\begin{array}{l}\text { Built 1992. Bullingdon design, with additional } \\
\text { mix of wings }\end{array}$ & 1215 & 9 & $\begin{array}{l}\text { Healthcare \& } \\
1 \text { Smoke-Free Spur }\end{array}$ & $\begin{array}{l}\text { October \& } \\
\text { November } 2014\end{array}$ \\
\hline
\end{tabular}

${ }^{a}$ Category B prisons hold prisoners for whom the very highest conditions of security are not necessary but for whom escape must be made very difficult ${ }^{a}$ Category $C$ prisons hold prisoners who cannot be trusted in open conditions but who do not have the resources and will to make a determined escape attempt ${ }^{a}$ Female closed prisons can hold category A, B, C prisoners. Due to the smaller female prisoner population, female establishments are categorised into either 'closed' or 'open'

aLocal prisons serve the courts and receive remand and post-conviction prisoners prior to their allocation to other establishments ${ }^{a}$ Training prisons hold sentenced prisoners who tend to be employed in a variety of activities such as prison workshops, education and in offending behaviour programmes 
were then approached by the researcher who explained the study, answered questions and requested written consent. Given consent, the SidePak monitor was generally placed on a shelf or desk at around waist height in the cell. Data on each cell location, the number of prisoners in the cell, their smoking status and the style of the cell window were recorded. Due to the gentle buzz the SidePak monitor makes whilst sampling it was placed in a cool box surrounded by foam padding. Data were typically collected for a few hours over a morning or afternoon period.

Prison Officers working in the prisons were contacted by email in advance of the study visit, or by word of mouth at the time the monitors were placed on wings or in cells, and invited to volunteer to wear a monitor for personal sampling. All who volunteered were given an explanation of the study and asked to provide written consent. We recruited both current smokers and nonsmokers. We measured exhaled carbon monoxide with a Smokerlyzer (Bedfont Scientific Ltd) at the start of our monitoring period, and then attached the SidePak monitor to their belt and used a short length of Tygon tubing to sample air from their breathing zone. A second measurement of exhaled carbon monoxide was taken when sampling finished, when the staff members also returned a timed $\log$ of their work locations and activities during the data collection period.

\section{Data analysis}

Since the SidePak monitors were usually turned on and off just before and after being placed in the sampling sites we discarded the first and last five minutes of each data record. Each set of sampling data was downloaded from the monitor using Trackpro 4.6.1 software, and transferred to a Microsoft Excel spreadsheet with the corresponding location, cell and staff member data. We then used STATA 13 to generate descriptive statistics including arithmetic means, $95 \%$ confidence intervals, standard deviations, ranges and times of maximum values, and to estimate the proportion of time in which the $\mathrm{PM}_{2.5}$ concentration exceeded World Health Organisation (WHO) $24 \mathrm{~h}$ mean $\mathrm{PM}_{2.5}$ upper limit of $25 \mu \mathrm{g} /$ $\mathrm{m}^{3}$ [14] for each dataset. Although $\mathrm{PM}_{2.5}$ data distributions were skewed, we present arithmetic as well as geometric mean figures since the former are used by the WHO to define upper limits. Log-transformed data were used for all t-test comparisons.

\section{Results}

In total 86 datasets were collected from wing landing, prison cells and personal monitoring. Three datasets were discarded because the monitor had been tampered with, leaving 83 for analysis. Prisoner roll count on the wings sampled varied from four to 180 . Details of the number of datasets, and arithmetic and geometric mean, median and range for each type of sample location, including a smoking/non-smoking breakdown, are presented in Table 2.

\section{Wing landings}

A total of 48 datasets were collected from 30 different smoking and non-smoking landing locations. Thirtyeight locations were sampled exclusively during the daytime period, and ten were sampled into the night time. The average period over which data were collected was 6.5 (Standard Deviation (SD) 2.0) hours. Arithmetic mean $\mathrm{PM}_{2.5}$ in the 48 data sets was $40.08 \mu \mathrm{g} / \mathrm{m}^{3}$, and ranged from 0 to $1124 \mu \mathrm{g} / \mathrm{m}^{3}$. Mean $\mathrm{PM}_{2.5}$ concentrations were significantly higher on landings where smoking was permitted in cells than non-smoking wing landings $\left(43.87 \mu \mathrm{g} / \mathrm{m}^{3}\right.$ and $5.90 \mu \mathrm{g} / \mathrm{m}^{3}$ respectively, $p<0.001)$. Of the 42 datasets from smoking locations, 18 landings spent over half of the sampling time over the WHO $24 \mathrm{~h}$ mean upper guidance limit of $25 \mu \mathrm{g} / \mathrm{m}^{3}$ (14). In the three prisons with a single canteen day (one prison was excluded from the analysis because its canteen delivery spanned two-three days, therefore no pre-canteen data were available), $\mathrm{PM}_{2.5}$ concentrations were also higher on smoking locations on the day after the canteen was delivered $\left(20.33 \mu \mathrm{g} / \mathrm{m}^{3}\right.$ before and $27.83 \mu \mathrm{g} / \mathrm{m}^{3}$ after, $p<$ 0.001 ). There was no difference in $\mathrm{PM}_{2.5}$ concentrations sampled from wings of different structural design. Continuous data from each smoking site sampled during the daytime are represented graphically in Fig. 1.

One establishment had a $\mathrm{T}$ shaped design wing comprising three identical spurs, one of which was voluntarily non-smoking. The spurs were connected by gated doors which allowed air to flow between them. SidePak monitors were run on the voluntary non-smoking and smoking spur simultaneously throughout the day and then again into the night (Fig. 2).

\section{Prison cells}

All 13 cells sampled were located on wings where smoking was permitted in cells, and five of the cells sampled had occupants who smoked. The average time for which data were collected was $4.88 \mathrm{~h}$ (SD 1.76) and the arithmetic mean of the 13 datasets was $103.10 \mu \mathrm{g} / \mathrm{m}^{3}$. High concentrations of $\mathrm{PM}_{2.5}$ were recorded in the five smokers' cells with means ranging from 62.31 to $434.74 \mu \mathrm{g} / \mathrm{m}^{3}$, and in all cases exceeded the WHO limit of $25 \mu \mathrm{g} / \mathrm{m}^{3}$ as a $24 \mathrm{~h}$ mean (14) for over $60 \%$ of the sampling time. The arithmetic mean $\mathrm{PM}_{2.5}$ concentration in smoking cells $\left(226.16 \mu \mathrm{g} / \mathrm{m}^{3}\right)$ were significantly higher than in nonsmoking cells $\left(16.98 \mu \mathrm{g} / \mathrm{m}^{3}, p<0.001\right)$. Figure 3 shows concentrations of $\mathrm{PM}_{2.5}$ recorded in a single cell where 
Table 2 Summary of data collected from SidePak monitors located on wing landings, prison cells and whilst attached to staff members

\begin{tabular}{|c|c|c|c|}
\hline \multirow[b]{2}{*}{$\mathrm{PM}_{2.5}$} & \multicolumn{3}{|c|}{ Sample locations } \\
\hline & Wing landings & Prison cells ${ }^{b}$ & Attached to staff members $^{a}$ \\
\hline Total Datasets (average duration, hours) & $48(6.5)$ & $13(4.88)$ & \\
\hline Arithmetic Mean $\left(\mu \mathrm{g} / \mathrm{m}^{3}\right)$ & 40.08 & 103.1 & \\
\hline Standard Deviation & 57.08 & 237.47 & \\
\hline Range & $0-1124$ & $0-2684$ & \\
\hline Median & 30.78 & 27.52 & \\
\hline Geometric Mean $\left(\mu \mathrm{g} / \mathrm{m}^{3}\right)$ & 32.57 & 59.2 & \\
\hline Interquartile Range & $16.40-35.85$ & $10.49-90.63$ & \\
\hline Non-Smoking Locations (average duration, hours) & $6(5.18)$ & $8(5.12)$ & \\
\hline Arithmetic Mean $\left(\mu \mathrm{g} / \mathrm{m}^{3}\right)$ & 5.90 & 16.98 & \\
\hline Standard Deviation & 2.90 & 15.46 & \\
\hline Range & $0-22$ & $1-102$ & \\
\hline Median & 5.71 & 13.39 & \\
\hline Geometric Mean $\left(\mu \mathrm{g} / \mathrm{m}^{3}\right)$ & 5.58 & 14.88 & \\
\hline Interquartile Range & $5.29-7.77$ & $6.9-25.82$ & \\
\hline Smoking Locations ${ }^{\complement}$ (average duration, hours) & $42(6.66)$ & $5(4.51)$ & $22(4.18)$ \\
\hline Arithmetic Mean $\left(\mu \mathrm{g} / \mathrm{m}^{3}\right)$ & 43.87 & 226.16 & 23.51 \\
\hline Standard Deviation & 58.95 & 333.08 & 34.01 \\
\hline Range & $1-1124$ & 8- 2684 & $2-608$ \\
\hline Median & 32.86 & 162.90 & 19.04 \\
\hline Geometric Mean $\left(\mu \mathrm{g} / \mathrm{m}^{3}\right)$ & $35.57^{*}$ & $122.52^{*}$ & 18.57 \\
\hline Interquartile Range & $18.9-36.97$ & $81.61-163.14$ & $11.37-18.59$ \\
\hline
\end{tabular}

*Two-sample t-test comparing smoking and non-smoking locations, denotes significance $(p<0.001)$

${ }^{a}$ All staff members sampled worked on locations where smoking was permitted in cells only

${ }^{b}$ All prison cells sampled were located on wings where smoking was permitted in cells only

'Smoking locations were those where smoking was permitted in cells only

the occupant smoked. The prisoner reported smoking four hand-rolled cigarettes during the sampling period.

Concentrations of $\mathrm{PM}_{2.5}$ in non-smokers cells were relatively low (arithmetic mean $16.98 \mu \mathrm{g} / \mathrm{m}^{3}$ ), though higher in non-smoking cells on wings with closed narrow corridors than more open designs. Figure 4 shows $\mathrm{PM}_{2.5}$ concentrations sampled simultaneously on a wing landing with closed narrow corridors and in a non-smoker's cell on the same landing. The wing landing had an arithmetic mean $\mathrm{PM}_{2.5}$ of $59.78 \mu \mathrm{g} / \mathrm{m}^{3}$ whilst the non-smoking cell located on this landing had a mean of $27.52 \mu \mathrm{g} / \mathrm{m}^{3}$, with concentration levels above the WHO $24 \mathrm{~h}$ upper guidance limit almost $50 \%$ of the time.

\section{Staff members}

Of the 22 staff members who volunteered for personal monitoring, 21 were prison officers and one a healthcare assistant. All were based on wings where smoking was permitted in cells and had prisoner contact. Twenty-one staff members were monitored during a daytime shift and one on a night shift. The average period of data collection was $4.18 \mathrm{~h}$. The arithmetic mean $\mathrm{PM}_{2.5}$ concentration to which participants were exposed was $23.51 \mu \mathrm{g} / \mathrm{m}^{3}$. Figure 5 shows concentrations of $\mathrm{PM}_{2.5}$ sampled from a single prison officer during a morning shift alongside their self-reported timed outline of locations and duties during sampling.

The location report for this individual suggested that higher exposure levels tended to occur during periods spent on the wing landings, a finding that was evident in records from all other staff members. Some of the highest concentrations of $\mathrm{PM}_{2.5}$ were recorded during duties such as locking or unlocking cells, handing out mail and cell searching. Lower $\mathrm{PM}_{2.5}$ concentrations were recorded during periods when staff members were located in the wing office, supervising medication (when the medication hatch was not located on the wing landing) and escorting prisoners off the wing. One prison had 3 staff members exposed to concentration levels above the WHO upper guidance limit of $25 \mu \mathrm{g} / \mathrm{m}^{3}$ [14] for over $80 \%$ of their sampling period. 

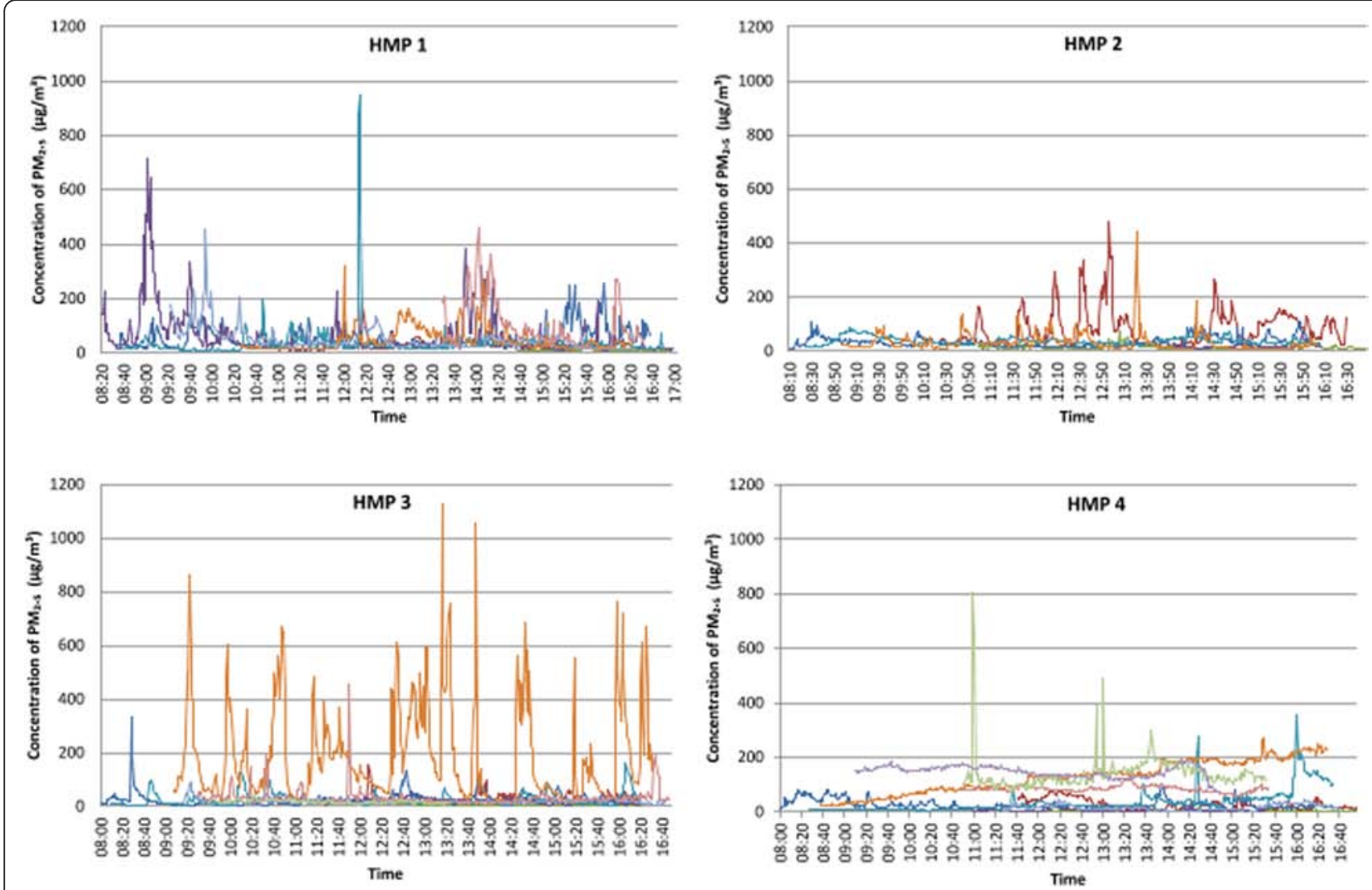

Fig. 1 Concentrations of $\mathrm{PM}_{2.5}$ recorded on smoking locations in all four prisons sampled over the day time periods

Carbon Monoxide concentrations in exhaled breath were measured in 21 of the staff members who wore a SidePak monitor. The readings confirmed the smoking status of the staff member participating but did not demonstrate any difference between measures at the start and end of shifts among non-smokers.

\section{Discussion}

This is the first study to measure particulate pollution from SHS in prisons in England. Our findings demonstrate that on wings where smoking was permitted in cells, concentrations of $\mathrm{PM}_{2.5}$ sampled on landings and from staff members working on them were high. Although we were for

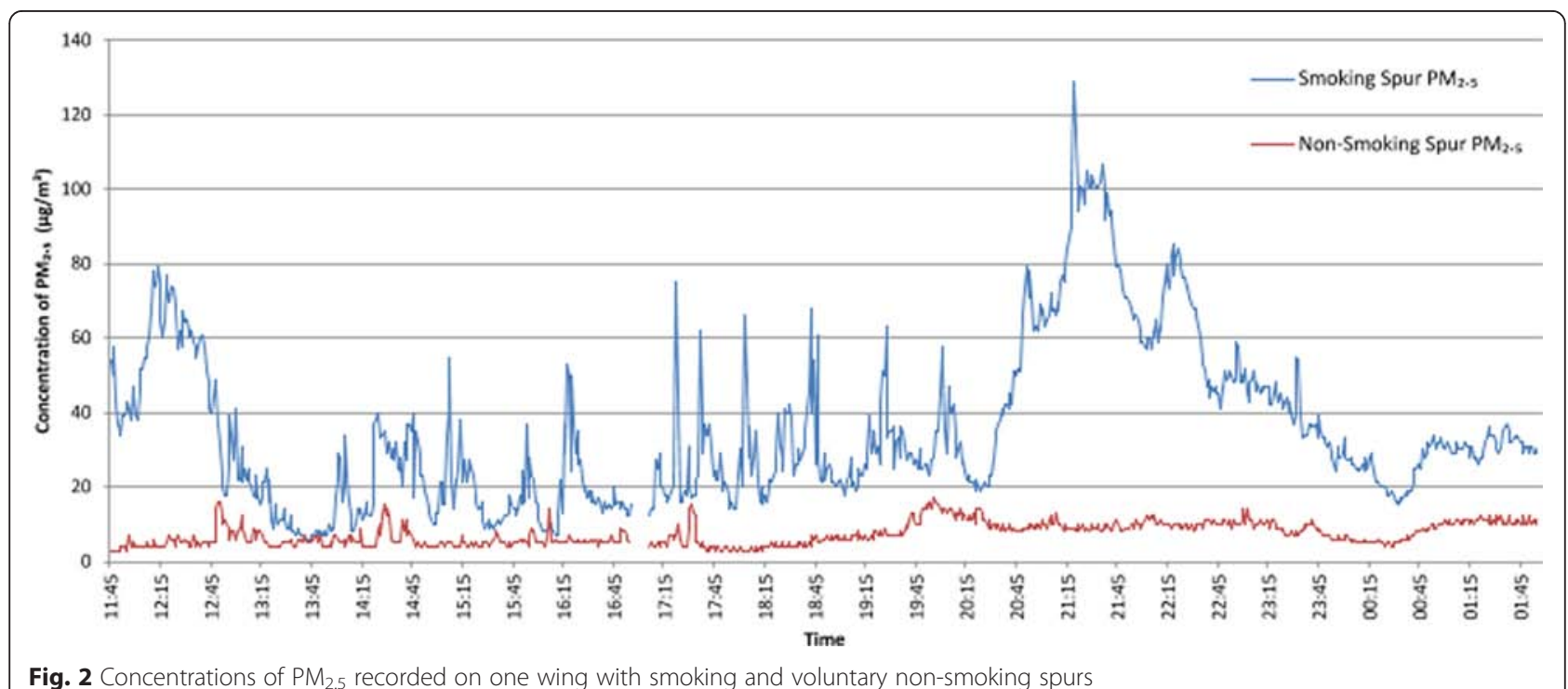

Fig. 2 Concentrations of $\mathrm{PM}_{2.5}$ recorded on one wing with smoking and voluntary non-smoking spurs 


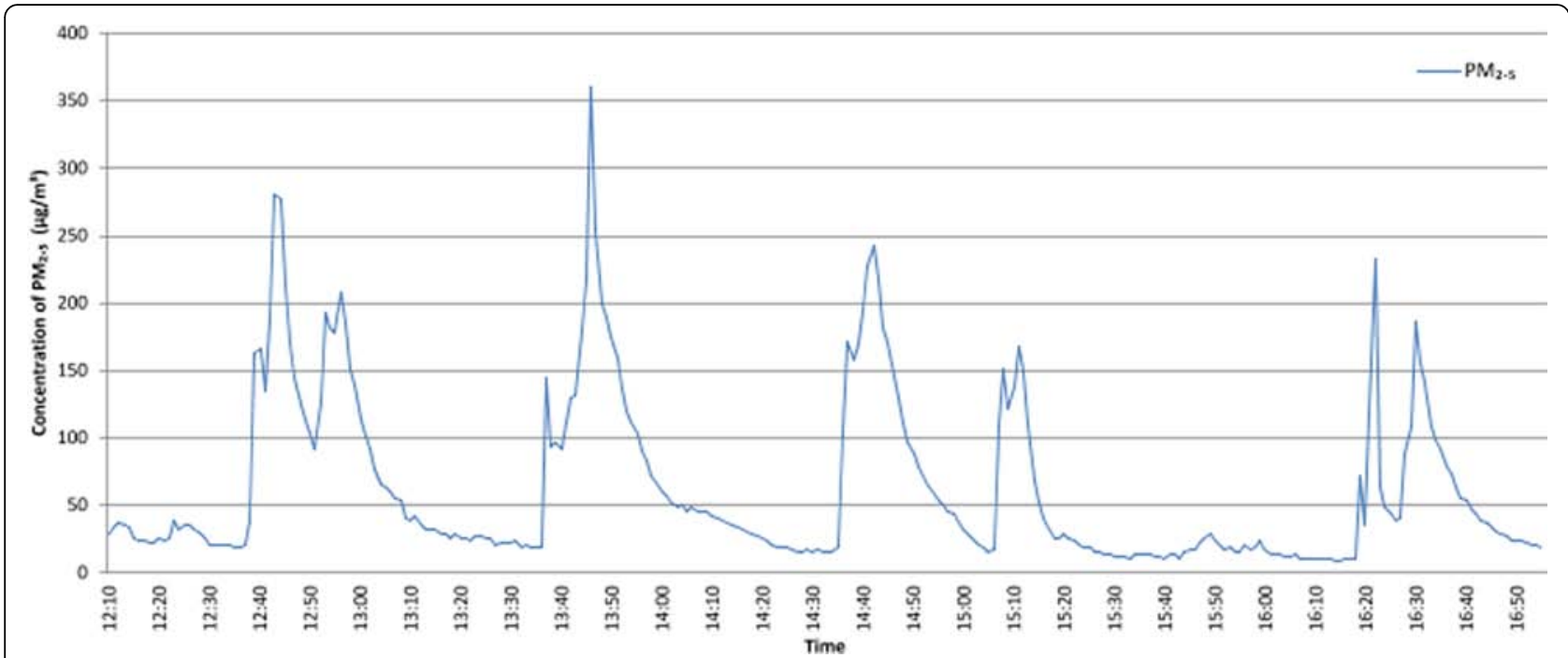

Fig. 3 Concentrations of $\mathrm{PM}_{2.5}$ recorded in a single smoker cell

logistical reasons unable to carry out full $24 \mathrm{~h}$ monitoring, the concentrations we measured often exceeded the WHO upper guidance limit of $25 \mu \mathrm{g} / \mathrm{m}^{3}$ as a $24 \mathrm{~h}$ mean [14], and in some locations did so for the entire period of monitoring. Levels of pollution in cells where smoking was permitted were particularly high. Some of the staff we monitored were exposed above the WHO limit for over $80 \%$ of their working day. Since SHS contains several thousand toxins and many carcinogens [2], the hazards associated with this exposure are likely to be significant. Smoking in prisons is thus a significant potential cause of harm to health in smokers and non-smokers in the prison setting, and including both prisoners and staff.

We used $\mathrm{PM}_{2.5}$ concentration as a marker for SHS $[11,12]$, since direct measurement of tobacco-specific toxins in the atmosphere is expensive and sampling methods would be impractical in prison settings. SHS is not the only source of indoor $\mathrm{PM}_{2.5}$, which includes particulate matter released from sources such as open fires, toasters and microwaves. However, where toasters and microwaves were present on the wings, every effort was made to place the SidePak monitors as far away from these as possible. We carried out much of our sampling during the summer months when natural ventilation to the wings and cells through open windows and doors would have been greater than during the winter months, potentially causing our findings to underestimate average pollution levels over the longer term. Safe locations for the SidePak monitors were limited, but we tried to collect data from a broad selection of settings. Since we were obliged to answer questions from staff members and prisoners who enquired about the monitoring, our measurements were not carried out blind. However, whilst it is possible that prisoners or staff changed their

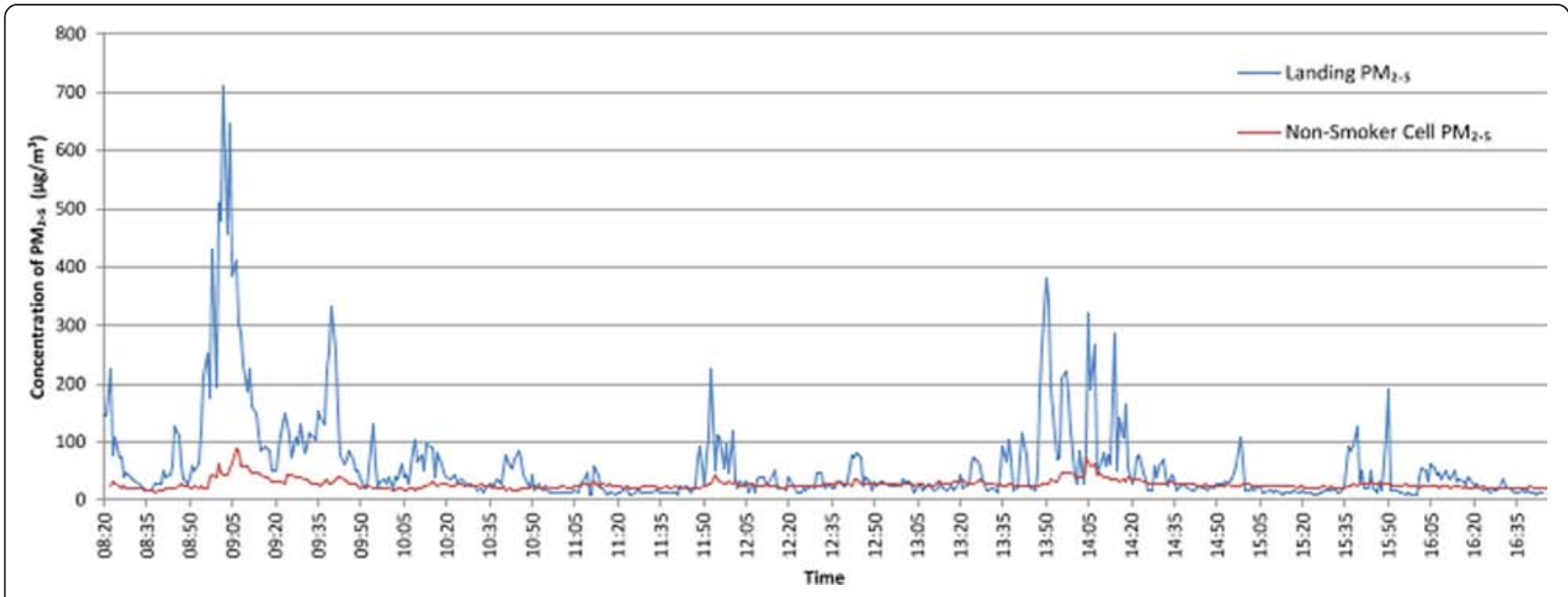

Fig. 4 Concentrations of $\mathrm{PM}_{2.5}$ sampled simultaneously on a landing and non-smokers cell from the same wing landing 


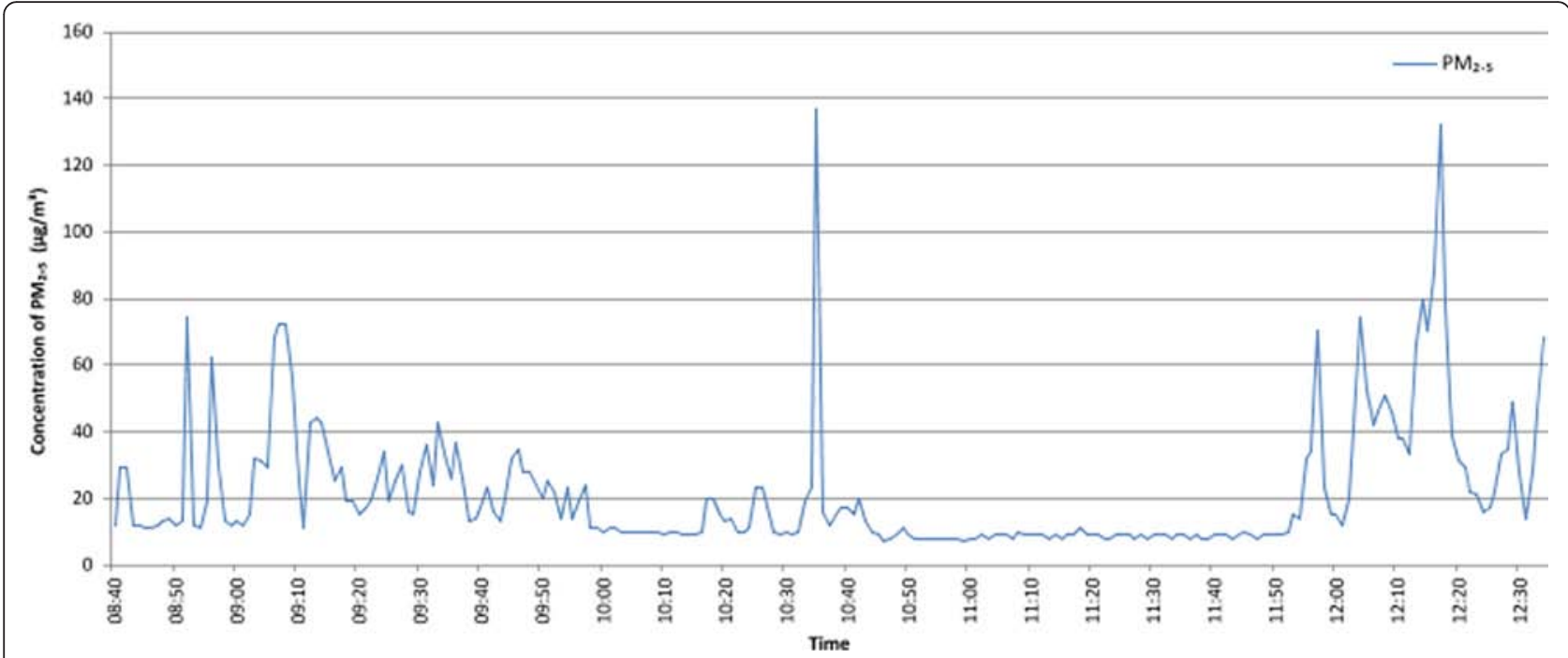

Fig. 5 Concentrations of $\mathrm{PM}_{2.5}$ sampled during a prison officer's morning shift. Prison officer self-reported locations and duties during sampling: 08:40-10:00 Wing landing; supervising, dealing with prisoner queries; 10:00-10:10 Wing office; 10:10-11:00 Wing landing; including entering a prisoner cell; 11:00-11:50 Wing office; checking emails and paperwork; 11:50-12:40 Wing landing; supervising lunch time and locking up prisoners

behaviour in response to being monitored, we think that is unlikely to have occurred to any appreciable degree over the course of our measurements. Our maximum sampling time was determined by a battery life of around $9 \mathrm{~h}$, though in practice we were also constrained by restrictions on the times that we could leave and collect the monitors. Prison staff who wore monitors were also limited by their shift patterns. For all these reasons our sampling does not provide fully representative $24 \mathrm{~h}$ sampling in the prisons; rather it reflects pollution levels at times during the day when prisoners were awake and more likely to be smoking. The proportion of monitoring times spent above WHO guidelines probably therefore overestimates the true $24 \mathrm{~h}$ average figures, but the concentration levels observed were at times very high. As a best case scenario, extrapolating the samples from wing locations to cover a $24 \mathrm{~h}$ period with an assumption that the times not sampled had a reading of zero, two wings still produced an arithmetic mean above the $25 \mu \mathrm{g} / \mathrm{m}^{3}$ WHO upper guidance limit.

In an evaluation of smoke-free policy within correctional facilities in North Carolina, USA, four facilities with no smoke-free legislation pre-policy recorded an arithmetic mean concentration of $\mathrm{PM}_{2.5}$ of $93.11 \mu \mathrm{g} / \mathrm{m}^{3}$ [16]. The arithmetic mean reported for all smoking wing landing datasets in this study is less than half (arithmetic mean $43.87 \mu \mathrm{g} / \mathrm{m}^{3}$ ) of that reported in North Carolina, even though they report a $65 \%$ prisoner smoking prevalence which, anecdotally, is broadly similar to that in England. Twelve datasets were collected from smoking locations in North Carolina (compared with 42 in this study) and the average time for data collection was $1.28 \mathrm{~h}$ (compared to
$6.66 \mathrm{~h}$ in this study). Another study, conducted in prisons in New Zealand [17] recorded $\mathrm{PM}_{2.5}$ concentrations before a smoke-free policy was introduced, and produced a geometric mean before the policy of $6.58 \mu \mathrm{g} / \mathrm{m}^{3}$. Although much lower than the geometric mean recorded across smoking locations in this study $\left(35.57 \mu \mathrm{g} / \mathrm{m}^{3}\right)$ the authors acknowledge that the representativeness of their findings was constrained by their decision, out of fears that the monitors would be tampered with, not to sample air in common areas used by prisoners. Samples were therefore taken only from the 'staff base', and did not reflect levels elsewhere in the prison.

Research evidence summarised by the WHO and others suggests that there is no safe level of exposure to SHS $[1,14]$. Data collected from staff members gave an insight into locations where exposures to $\mathrm{PM}_{2.5}$ were highest, and these included the wing landing, and at the doorway and inside a prisoner's cell. Taken together, these findings can offer some guidance as to the types of wings or duties where staff members are exposed to the highest levels of SHS and therefore where protection from SHS is particularly needed.

Prisoners in England who want to avoid SHS exposure are entitled to request a non-smoking cell, but our findings suggest that being in a non-smoking cell does not necessarily offer protection against SHS, especially for those on wings with closed narrow corridors. Staff members are also able to opt to work in smoke-free areas of the prison, but such opportunities are relatively rare, resulting in significant exposure for many staff. SHS exposure of pregnant women is also a significant potential hazard [3] for both prisoners and staff members; at the time that this study was carried 
out, pregnant prisoners were not usually transferred to a smoke-free environment until they have given birth. During data collection at the female closed prison there were 18 pregnant prisoners living on main prison locations, though their smoking status was not known.

Our findings thus provide strong evidence that smoking in prisons in England is a source of high SHS exposure for both staff and prisoners and therefore the current PSI relating to smoking in English and Welsh prisons requires revision. It is likely that our findings are also representative of exposures in similar prison systems in other countries. It is self-evident that this exposure would be reduced by promoting smoking cessation amongst staff and prisoners, increasing the amount of voluntary smoke-free wings and ultimately prevented by making prisons comprehensively smoke-free.

\section{Conclusions}

This is the first study to measure levels of $\mathrm{PM}_{2.5}$ as a proxy measure for second-hand smoke in English prisons and demonstrates high levels of smoke pollution in areas of the prisons where people smoke, this therefore represents a significant health hazard to prisoners and staff members. The study provides scientific evidence in support of a national smoke-free prison policy.

\section{Ethical approval}

Ethics approval for the study was provided by the University of Nottingham Medical School Ethics Committee (G06062013 CHS EPH) and the National Offender Management Service National Research Committee (Ref: 2013-202) in July 2014. Permission to enter all four prisons to conduct this study was sought from the Deputy Director of Public Sector Prisons and the Deputy Director of Custody for the South West Area. The four Governors from each establishment also agreed to the research.

\section{Patient consent and consent to publish}

All participants gave informed consent before taking part in the study. This included, consent to publish individual participant datasets.

\section{Data sharing}

Additional data from the study can be obtained on request from the corresponding author.

\section{Competing interests}

The authors declare that they have no competing interests.

\section{Authors' contributors}

$\sqcup J$ is the guarantor and takes responsibility for the integrity of the work as a whole, from inception to publication; contributed to the study conception and design, acquisition of data, analysis of the data, interpretation of data and drafting the article. ER, RM, SD-W and JB contributed to the study conception and design. ER, RM and JB contributed to the interpretation of data and drafting the article. All authors read and approved the final version of the manuscript.

\section{Acknowledgments}

We would like to thank the four participating prisons that made this study possible, especially the staff members for their time and expertise throughout data collection.

\section{Funding}

This study was funded by a UK Centre for Tobacco and Alcohol Studies PhD studentship.

\section{Author details}

${ }^{1}$ UK Centre for Tobacco and Alcohol Studies and Division of Epidemiology and Public Health, University of Nottingham, Clinical Sciences Building, Nottingham City Hospital, Nottingham NG5 1PB, UK. ${ }^{2}$ National Offender Management Service, Clive house, 70 Petty France, London SW1H 9EX, UK.

Received: 12 October 2015 Accepted: 20 January 2016 RP?

\section{References}

1. U.S. Department of Health and Human Services. The Health Consequences of Involuntary Exposure to Tobacco Smoke. Atlanta, GA: A Report of the Surgeon General; 2006.

2. Royal College of Physicians. Going smoke-free: the medical case for clean air in the home, at work and in public places. London: A report on passive smoking by the Tobacco Advisory Group of the Royal College of Physicians; 2005.

3. Royal College of Physicians. Passive smoking and children. London: A report by the Tobacco Advisory Group of the Royal College of Physicians; 2010.

4. HM Government. Health Act 2006. Chapter 28. Great Britain: Smoking; 2006.

5. Callinan JE, Clarke A, Doherty K, et al. Legislative smoking bans for reducing secondhand smoke exposure, smoking prevalence and tobacco consumption. Cochrane Database Syst Rev. 2010;14:4.

6. Mackay D, Haw S, Ayres JG, et al. Smoke-free legislation and hospitalizations for childhood asthma. N Engl J Med. 2010;363(12):1139-45.

7. Mackay DF, Irfan MO, Haw S, et al. Meta-analysis of the effect of comprehensive smoke-free legislation on acute coronary events. Heart. 2010;96(19):1525-30

8. Millett C, Lee JT, Laverty AA, et al. Hospital admissions for childhood asthma after smoke-free legislation in England. Pediatrics. 2013;131(2):495-501.

9. HM Prison Service. Prison Service Instruction 09/2007. London: Smoke free legislation: prison service application; 2007.

10. Singleton N, Farrell M, Meltzer H. Substance misuse among prisoners in England and Wales. International review of psychiatry. 1999;15(1-2):150-2.

11. Sureda X, Fernandez E, Lopez MJ, et al. Secondhand tobacco smoke exposure in open and semi-open settings: a systematic review. Environ Health Perspect. 2013;121(7):766-73.

12. Hyland A, Travers MJ, Dresler C, et al. A 32-country comparison of tobacco smoke derived particle levels in indoor public places. Tob Control. 2008; 17(3):159-65.

13. Semple S, Apsley A, Galea KS, et al. Secondhand smoke in cars: assessing children's potential exposure during typical journey conditions. Tob Control. 2012.

14. World Health Organisation. WHO air quality guidelines. Geneva, Switzerland: Global Update; 2005

15. Ritter C, Huynh CK, Etter JF, et al. Exposure to tobacco smoke before and after a partial smoking ban in prison: indoor air quality measures. Tob Control. 2012:21(5):488-91.

16. Proescholdbell SK, Foley KL, Johnson J, et al. Indoor air quality in prisons before and after implementation of a smoking ban law. Tob Control. 2008;17(2):123-7.

17. Thornley S, Dirks KN, Edwards R, et al. Indoor air pollution levels were halved as a result of a national tobacco ban in a New Zealand prison. Nicotine Tob Res. 2013;15(2):343-7.

18. Semple S, van Tongeren M, Galea KS, et al. UK smoke-free legislation: changes in PM2.5 concentrations in bars in Scotland, England, and Wales. Ann Occup Hyg. 2010;54(3):272-80.

19. Jiang RT, Acevedo-Bolton V, Cheng KC, et al. Determination of response of real-time SidePak AM510 monitor to secondhand smoke, other common indoor aerosols, and outdoor aerosol. J Environ Monit. 2011;13(6):1695-702. 